\title{
Understanding dystonia: diagnostic issues and how to overcome them
}

Compreendendo a distonia: questões diagnósticas e como superá-las

Sarah Camargos, Francisco Cardoso

\begin{abstract}
The diagnosis and treatment of dystonia are challenging. This is likely due to gaps in the complete understanding of its pathophysiology, lack of animal models for translational studies, absence of a consistent pathological substrate and highly variable phenotypes and genotypes. The aim of this review article is to provide an overview of the clinical, neurophysiological and genetic features of dystonia that can help in the identification of this movement disorder, as well as in the differential diagnosis of the main forms of genetic dystonia. The variation of penetrance, age of onset, and topographic distribution of the disease in carriers of the same genetic mutation indicates that other factors - either genetic or environmental - might be involved in the development of symptoms. The growing knowledge of cell dysfunction in mutants may give insights into more effective therapeutic targets.
\end{abstract}

Keywords: dystonia; apoptosis.

\section{RESUMO}

O diagnóstico e o tratamento da distonia podem ser desafiadores. Isso se dá provavelmente a pouca compreensão da fisiopatologia, a falta de modelos animais para estudos translacionais, ausência de um substrato patológico consistente e genótipo e fenótipo altamente variáveis. O objetivo deste artigo de revisão é fornecer uma visão geral dos aspectos clínicos, neurofisiológicos e genéticos de distonia que podem ajudar na identificação deste distúrbio do movimento, bem como no diagnóstico diferencial das principais formas de distonia hereditária. Há uma ênfase particular na nova definição e classificação da Internacional das Distonias, bem como as recentes descobertas dos mecanismos moleculares subjacentes em algumas formas de distonia primária. A variação de penetrância, idade de início, e distribuição topográfica da doença em portadores da mesma mutação genética indica que outros fatores - genéticos ou ambientais podem estar envolvidos no desenvolvimento dos sintomas. O conhecimento crescente sobre a disfunção celular em mutantes pode gerar insights sobre alvos terapêuticos mais eficazes.

Palavras-chave: distonia; apoptose

\section{INTRODUCTION AND HISTORICAL ASPECTS}

Etymologically, the word dystonia comes from the Greek language and means altered muscle tone. According to the first Oppenheim definition in 1911, the "muscle tone was hypotonic at one occasion and in tonic muscle spasm at another, usually, but not exclusively, elicited upon voluntary movements".

The first description of dystonia dates back to the end of the 19th century and is by Barraquer-Roviralta although not recognized as such ${ }^{1}$. Later, in 1911, Herman Oppenheim coined the term "dystonia musculorum deformans" for the description of this movement disorder in a Jewish patient ${ }^{1}$. Contrary to the prevailing view of that time, he proposed an organic origin of the disease. As time progressed, several pieces of evidence supported the organic nature of dystonia: the hereditary mechanism, limited efficacy of psychotherapy, good response to thalamotomy or pallidotomy and, finally, the onset of dystonia following brain lesions in monkeys ${ }^{2}$. In June of 1975, Stanley Fahn and Roswell Eldridge chaired an International Symposium on Dystonia in New York City. At the conference, David Marsden described sporadic forms of dystonia and defined its focal forms (for instance, cervical dystonia, blepharospasm, oromandibular dystonia and writer's cramp) as 'formes frustres' of generalized dystonia. He, and other authors who attended this meeting, emphasized the organic foundation of dystonia. At that conference, Masaya Segawa reported patients with dopa-responsive dystonia (DRD), for the first time outside Japan². In 1984, the Ad Hoc Committee of the Dystonia Medical Research Foundation defined dystonia as "a syndrome of sustained muscle contractions frequently causing twisting and repetitive movements or abnormal postures"3. Other important hallmarks in the 
history of dystonia were the discovery and description of the DYT1 locus and gene in, respectively, 1989 and $1997^{4}$.

During the last two decades, there has been a remarkable growth of research in the field of dystonia with a multitude of studies encompassing genetics, molecular biology, clinical aspects, as well as pharmacological and surgical treatment. For instance, the word dystonia has 15,774 PubMed citations, 1,366 being in the last two years. Recently, Broussolle et al. shed light on the history of the geste antagoniste phenomenon in dystonia ${ }^{5}$. Figure 1 shows a brief timeline in dystonia.

\section{MOVING TOWARDS A NEW DEFINITION AND NEW CLASSIFICATION}

Fahn classified dystonia according to age at onset, topographic distribution and etiology. The latter included primary, secondary and psychogenic dystonia ${ }^{3}$. Later, Bressman ${ }^{6}$ defined primary dystonia as those cases where dystonia is the sole phenomenon and there is no structural brain lesion or inborn error of metabolism. In her classification, secondary dystonia is characterized by the combination of dystonia and other abnormalities in the neurological examination. It includes dystonia plus (genetic forms where dystonia is combined with another movement disorder such as parkinsonism and myoclonus), heredodegenerative dystonia (genetic degenerative diseases where dystonia is part of the picture), acquired dystonia (the movement disorder results from a defined acquired cause such as stroke, use of neuroleptics and many others) and psychogenic dystonia ${ }^{6}$. Recently, a consensus committee sponsored by the Dystonia Medical Research Foundation, Dystonia Coalition and European Dystonia Cooperation in Science and Technology has proposed a new definition and classification of dystonia $^{7}$. The new definition, based on some pivotal features of the abnormal movement, attempts to overcome shortcomings from the past:

"Dystonia is a movement disorder characterized by sustained or intermittent muscle contractions causing abnormal, often repetitive, movements, postures, or both. Dystonic movements are typically patterned, twisting, and may be tremulous. Dystonia is often initiated or worsened by voluntary action and associated with overflow muscle activation ${ }^{7}$."

In the new classification system, there are two axes: clinical features and etiology, as shown in Figure 2. For clinical features, one should note age at onset, topographic distribution, temporal pattern and other associated movement disorders or manifestations. With reference to etiology, important aspects to be defined are: whether dystonia is inherited, acquired or idiopathic, as well as whether there is evidence of central nervous system pathology (degeneration or static lesion) ${ }^{7}$.

From a clinical point of view, the new classification has not introduced substantial changes. The most notable difference is the acknowledgement that tremor may be the main manifestation of dystonia. However, there are aspects that were not received with unanimous approval, such as the use of the word "idiopathic", a previously abandoned term ${ }^{7}$.

\section{HOW DOES IT MOVE? PHENOMENOLOGY}

The first and most important question related to the clinical aspect of dystonia is how to identify the phenomenon. Sometimes this is a difficult task, especially when there are other movement disorders involved. The new classification, and occasionally resorting to neurophysiological studies, provides guidance on how to diagnose dystonia, even in challenging cases.

\section{Clinical Features}

\section{Postures and movements}

One of the most important features of dystonia is the predictability and patterned nature of the muscle contractions. This makes it unique when compared to other hyperkinetic disorders. Contractions can be sustained, fixed or intermittent and sometimes mixed with tremor. This tremor can be rhythmic or irregular with occasional jerks ${ }^{8}$. Dystonic postures are when a body part is flexed or twisted along its longitudinal axis (except for blepharospasm and laryngeal dystonia). Dystonic movements, are usually twisting in nature

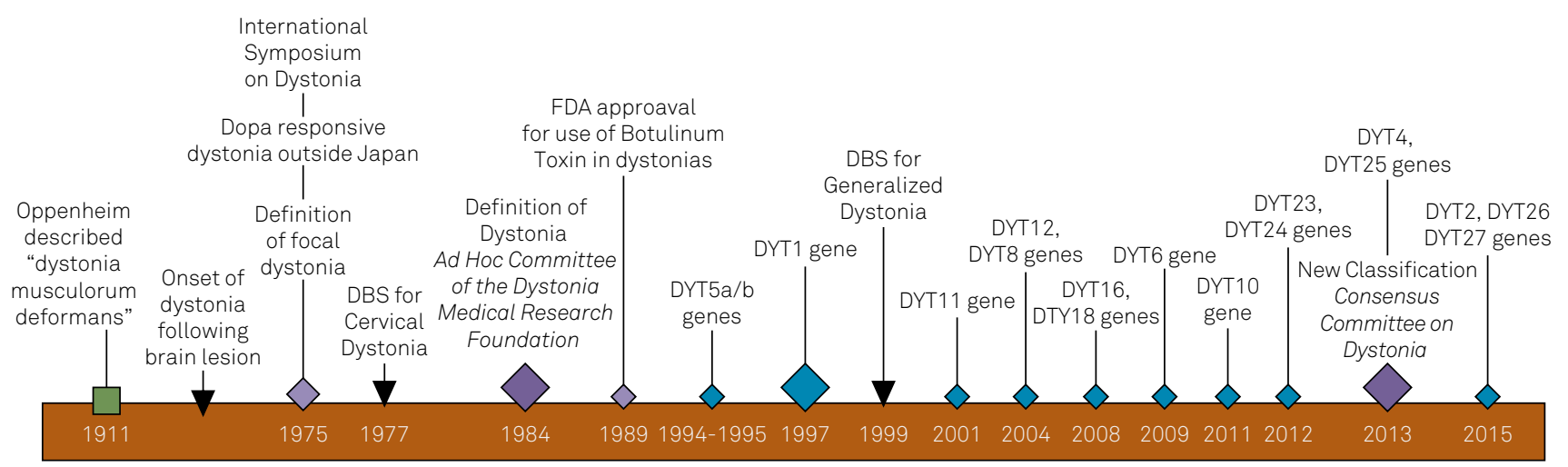

Figure 1. Timeline of dystonia. 


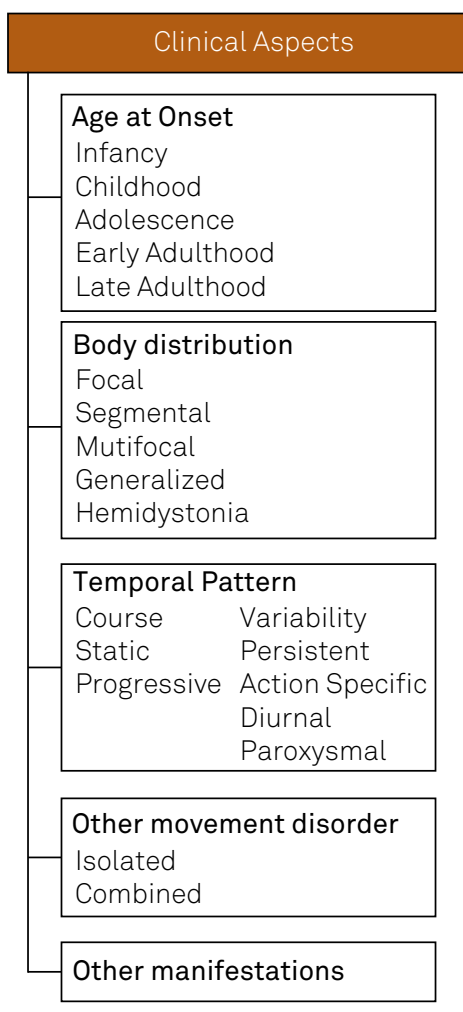

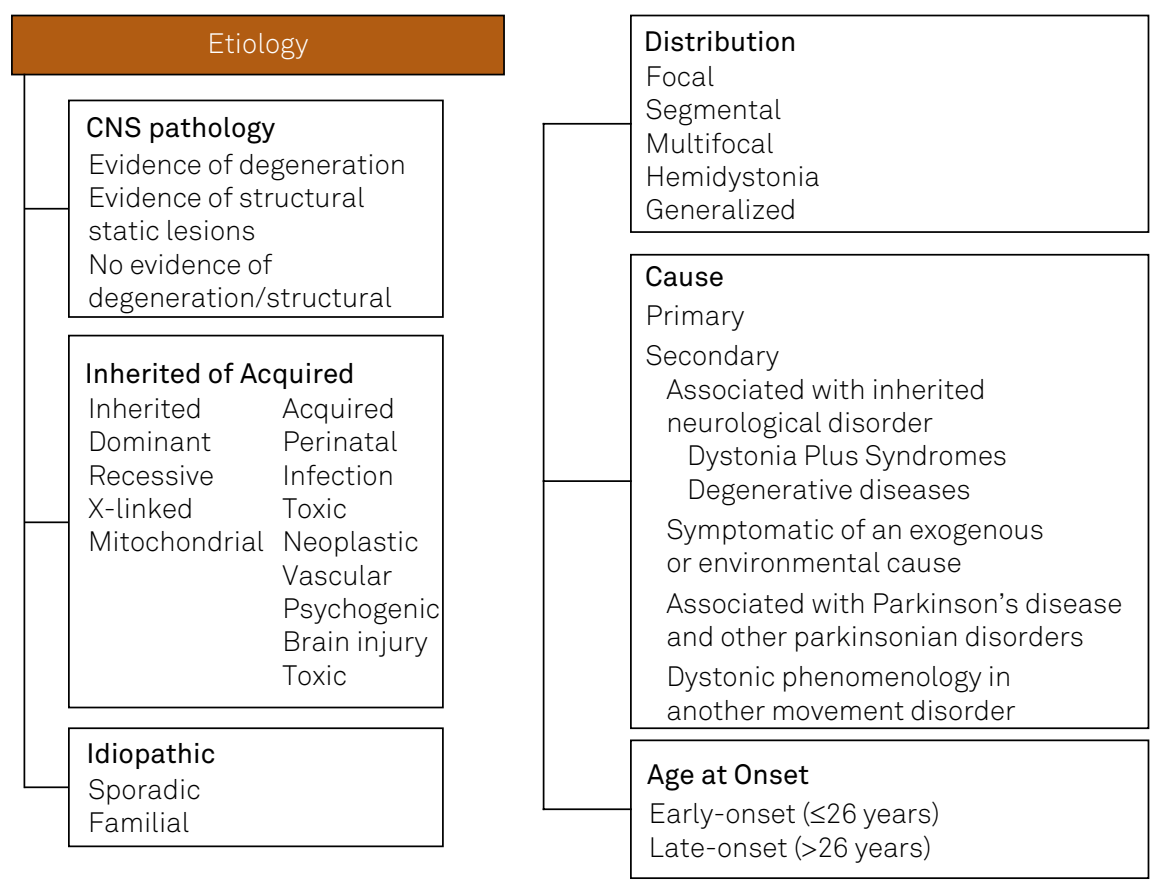

Figure 2. New Classification of dystonia based on two axes (Adapted from Albanese et al in Mov Disord. 2013;28:863-873) and the previous Classification of Dystonia (Geyer \& Bressman, Lancet Neurol. 2006; 5: 780-90)

or a pull in a preferred direction. Movements are sustained at their peak and lessen when a given posture is reached ${ }^{8}$. According to the new definition, dystonia is often initiated or worsened by voluntary action.

\section{Sensory trick or geste antagoniste}

Sensory tricks are often, but not exclusively, tactile stimuli, usually in the body part affected by the movement disorder, that produce a meaningful alleviation of dystonia ${ }^{5}$. They are usually simple natural movements, never forceful, involving the body region affected by dystonia. Physiological studies with electromyography (EMG) have shown a modification in recruitment during the effect of sensory tricks. However, the underlying mechanism remains to be determined. Loyola et al. hypothesized that sensory tricks may induce a rebalancing of central processing by reducing the activation of the supplementary motor area and primary sensory motor cortex 9 .

\section{Overflow}

Overflow is defined as the extension of muscle contraction into an adjacent area anatomically distinct from the primary movement when dystonic posture reaches a peak. A voluntary compensatory posturing may not easily be distinguishable from overflow ${ }^{7,8,10,11,12}$. Usually, voluntary movements are slower and more variable. According to Hallett, overflow is the clinical representation of impairment of normal surrounding inhibition present in dystonia ${ }^{12}$. According to this hypothesis, there is an imbalance of abnormal sensorimotor integration circuitry and cortical excitability. As a result, afferent inputs are inadequately processed at several levels of the central nervous system. This remodeled system creates an efferent output of abnormal co-contraction with the absence of surrounding inhibition ${ }^{11}$.

\section{Mirroring}

Mirror dystonia occurs on the affected body side when a specific task (e.g., writing, finger sequence, piano-like movements) is performed by the homologous opposite normal body part. It could be considered as a subset of motor overflow. The existence of simultaneous activation of the cortical spinal pathway, mediated by the impaired inhibition of transcallosal commissure, has been hypothesized ${ }^{7,8,10,11,12,13}$.

\section{DIFFERENTIAL DIAGNOSIS}

The recognition of dystonia is sometimes a difficult task, at least in part due to a combination of more than one hyperkinetic movement disorder and even to the overlapping of hyperkinesia and bradykinesia. Diagnosis is essentially a clinical one and should be preceded by meticulous information and observation of movement, including the onset, spread, duration, rhythmicity, topography and predictability ${ }^{8}$. Dystonia may mimic several movement disorders: phasic movements can resemble tremor, myoclonus and even tics. 
Tremor is an involuntary, patterned and rhythmic oscillation of a body region around a joint axis, generating a symmetric velocity in both directions at midpoint of the movement ${ }^{8}$. Differently, dystonic tremor can be arrhythmic, has irregular amplitude and superimposed jerks. Myoclonus is an intermittent condition, a sudden, brief, shock-like movement caused by muscular contractions or inhibitions. Dystonia has a sustained component not seen in myoclonus. Tics are paroxysmal, stereotyped muscle contractions, temporally suppressible and usually have a premonitory sensation and relief after performance. Partial suppression and a premonitory sensation are hallmarks that differentiate tics from dystonia. Abnormal postures can be present in several disorders without representing an involuntary dystonic muscle contraction. These contractions, called pseudodystonias, have a myriad causes, including orthopedic, ocular, vestibular, inflammatory, rheumatologic, peripheral (soft tissues, muscle, ligaments) or central problems ${ }^{14,15}$. Table 1 lists the specific causes of pseudodystonia. Striatal hands, camptocormia and Pisa syndrome are examples of abnormal postures usually seen in patients with Parkinson's disease (PD) with an unknown etiology. Different from the majority of dystonias, striatal hands are fixed, don't worsen with activity nor do they disappear during sleep. Camptocormia and Pisa syndrome are postural deformities in which, respectively, there is an abnormal anteroposterior flexion of the trunk or its marked lateral flexion. These conditions have been observed in several diseases such as PD, multiple system atrophy, different dystonias, Tourette syndrome, myotonic dystrophy, osteo and musculoskeletal disorders, myopathies, amyotrophic lateral sclerosis, and drug-induced conditions. An interesting feature is that these postures are reversible when the patient stands against a wall, uses a high frame walker or lies flat ${ }^{15}$. Some may interpret such facts as sensory tricks. Other evidence suggests they have a dystonic etiology with a few studies demonstrating EMG changes associated with dystonia and its occasional improvement with botulinum toxin ${ }^{14}$. However, it has been proposed that the dystonic phenomenon, if it exists, has a short presentation as an early phenomenon. Ultimately, in the later stages, dystonia disappears with soft tissue, muscle and spine problems dominating the picture ${ }^{14,15}$.

Fixed dystonia is characterized by a sustained abnormal limb posture regardless of other factors ${ }^{16}$. It is most commonly associated with severe cases of primary or secondary dystonia, corticobasal syndrome or in association with complex regional pain syndrome (types I and II without/with preceding nerve injury). This condition was previously labeled as "reflex sympathetic dystrophy" or "causalgia-dystonia"16. Interestingly, in 1892, Charcot described two patients with a combination of pain, edema, discoloration of skin associated with paralysis, contractures and an hysterical condition ${ }^{16}$. Whether fixed dystonia is a functional/psychogenic movement disorder or not is still a matter of debate. Several studies have shown that a number of patients fulfill the criteria for psychogenic or somatoform disorder ${ }^{16}$. Typically, fixed dystonia develops subacutely in the distal limb of young women, sometimes spreading to other limbs in a characteristic flexed position without overflow or geste antagoniste. However, a small percentage of patients with fixed dystonia in the context of complex regional pain syndrome remain without a psychiatric diagnosis ${ }^{16}$.

A challenging differential diagnosis is psychogenic dystonia. Usually, movement is both inconsistent and incongruous in an organic movement disorder. Electrophysiological testing is a valuable clinical tool (see below). Movement may disappear with distraction and be enhanced by suggestion. Commonly, psychogenic dystonias are fixed at onset, have excessive pain or fatigue and potential for secondary gain. Patients frequently have a history of multiple somatizations and psychiatric disturbance. Definite diagnosis requires repeated and extensive evaluations. The prognosis is usually poor ${ }^{2,16}$.

\section{Tremor and Dystonia}

Dystonia may erroneously be interpreted as tremor. Dystonic tremor is frequently misdiagnosed as essential tremor or Parkinson disease.

Dystonic tremor is defined as dystonia that manifests itself mostly with tremor ${ }^{17}$. Isolated head tremor, presentation of head tremor before arm tremor and more severe head tremor than arm tremors are virtually all manifestations of dystonic tremors. An interesting clue is that in essential tremor, head tremor often disappears when the patient lies down but persists in cervical dystonia ${ }^{18}$. Cases of isolated voice tremor predating the onset of hand tremor, and being more severe than hand tremor, is considered to be "tremulous dystonia"17. Usually dystonic tremors have irregular amplitudes and superimposed jerks.

When tremor occurs in the dystonia site, it is called dystonic tremor. This is a phenomenon that has received more attention lately. Tremor can be present in approximately $30 \%$ of subjects with dystonia. According to Erro et al., the prevalence of resting tremor among tremulous dystonic patients is $12 \%$ of all dystonic patients ${ }^{17}$. This study demonstrated that rest tremor in dystonic patients is mostly unilateral or asymmetric and, remarkably, does not have re-emergent tremor. The latter is a postural rest tremor in PD that reappears after a variable delay while maintaining posture. Not surprisingly, a diagnosis of PD is quite common in this group of patients. Different from PD, SPECT imaging of dopamine transporter shows an intact nigrostriatal pathway. This led to the coining of the term SWEDD (scan without evidence of dopaminergic deficit). This terminology was developed after agonist monotherapy trials identified patients with clinical diagnosis of PD but normal scans. Several SWEDD patients turned out to have dystonic 
Table 1. Conditions that may mimic dystonia.

\begin{tabular}{lcc}
\hline Variable & Cause & Pitfalls \\
\hline Tremor & Tremor associated to dystonia \\
$\begin{array}{l}\text { Other movement } \\
\text { disorders }\end{array}$ & Chorea & Rhythmic and oscillatory movements \\
& Myoclonus & Jerk-like movements resembling \\
dics & Dystonic tremor
\end{tabular}

Sandifer syndrome
Systemic disorders $\quad$ Stiff person
$\begin{gathered}\text { Rheumathoid arthritis, } \\ \text { juvenile idiopathic } \\ \text { arthritis, and juvenile } \\ \text { rheumatoid arthritis }\end{gathered}$

Atlanto axial subluxation

Orthopedic

Peripheral disorders (muscle, ligaments, vessels and bones)

Arteriovenous fistula at
the craniocervical junction
(or elongated vertebral
artery loop and dilatation of
vertebral artery)

Grisel's syndrome

\section{Epilepsy}

Arnold Chiari malformation

Central disorders

Posterior fossa tumor
Opisthotonic posturing mainly involving the neck, back, and upper extremities

Axial rigidity and stiffness superimposed by spasms caused by continuous firing of the peripheral nerve axons

Non traumatic anteroposterior atlanto-axial subluxation

Loss of range of motion and increased muscle tone due to dislocation of a joint and atlanto-axial rotatory misalignment

Unilateral shortening of the sternocleidomastoid muscle that is detected at birth or after birth

Muscle cramps, stiffness and delayed muscle relaxation.

Proximal myopathy with dropped neck

Space occupying lesion causing neck deviation

Compression of accessory nerve, meningeal irritation and change in bone supply affecting vestibular nuclei complex causing torticollis

Subluxations of the atlantoaxial joint from inflammatory ligamentous laxity following an infectious process

Intermittent tonic contractions

Intermittent and unusual neck posturing usually associated

Intermittent head tilt or twist associated with vomiting and headache
Tremor happens in another body part affected by dystonia and there is no directional predominance of the movement

\section{Unpredictability}

\section{EMG shows myoclonic features}

Frequently associated with premonitory sensation and relief after performance. Changeable over time.

Spasms occurring after feeding with pain Videotelemetry confirms.

EMG: continuous motor unit activity with normal morphology.

Stiffness, pain and limited movement plus inflammatory signs (swollen, red or warm) joints

RX: Distance between the anterior aspect of the dens and posterior aspect of the anterior arch of the atlas is more than $3 \mathrm{~mm}$

Neck ultrasonography confirms the existence of the neck mass or hypertrophy of the sternocleidomastoid muscle

EMG: grouped and complex discharges of motor units

Cervical paraspinal weakness that results in passively and correctable chin on chest deformity

$$
\text { Cervical bulging }
$$

MRI reveals vascular malformation at the craniocervical junction. Other symptoms may follow the attacks of torticollis: headache, drowsiness, papilledema, corticobulbar or corticospinal signs

RX reveals subluxation. Radicular and medullar signs can occur

\section{EEG shows epileptiform abnormalities}

Usually associated with posterior fossa dysfunction signs and pain

Other neurological signs such as increased intracranial pressure and localizing signs. Torticollis can be the first sign of central nervous system tumor.

Brain image reveals the diagnosis

Eye deviation with strabismus.
Troclear nerve palsy/ Lateral rectus palsy/Vestibular torticollis
Abnormal head posture adopted to improve visual acuity and maintain binocular single vision 
tremor with some peculiarities revealed by the underlying dystonic nature of the movement disorder ${ }^{19}$ :

1) position/task specificity

2) Jerkiness

3) presence of tremor-flurries, thumb hyperextension

4) pronation-supination type rather than vertical

5) absence of remarkable response to levodopa

6) Static rather than progressive disease.

Although SWEDD patients may have a slow gait, small stride length and reduced arm swing, they have a normal trunk and elbow posture, normal stride length variability and normal bilateral step phase coordination. These features differentiate them from patients with $\mathrm{PD}^{20}$. A long-term followup study of 16 patients with dystonic tremor resembling PD and SWEDD, at least five years after initial scan, demonstrated reduced striatonigral uptake in two patients and thus conversion to $\mathrm{PD}^{21}$. In summary, the majority of SWEDDs turned out to have dystonic tremor, but a small proportion of them may still develop PD after some time.

\section{SPECIAL ISSUES}

\section{Neurophysiology as a clinical tool}

According to some authors, EMG mapping is the "only clinical tool with a proven value for the diagnosis of dystonia to complement clinical examination". Although the previous statement is debatable, neurophysiologic studies can sometimes help define the nature of the movement. The usual features of dystonia on neurophysiological studies are:

1) Prolonged EMG bursts (200-500ms)

2) Simultaneous contractions (co-contraction) of agonist and antagonist muscles

3) Abnormal voluntary control of muscles with somatotopic contiguity (overflow): contraction of surrounding? muscles through impaired inhibition of spinal and medulla reflexes ${ }^{12}$.

If dystonic postures and movements have all the phenomenological features described above; or if at least two of the activation/deactivation features (tricks, mirroring, overflow) diagnostic criteria are met; or if one of the above plus EMG mapping demonstrating features of dystonia (such as abnormal activation, co-contraction and overflow), this can help clinical diagnosis ${ }^{8}$. These proposed criteria need to be validated before they can be incorporated into regular clinical practice ${ }^{8}$.

\section{Non-motor features}

It is widely known that several genetic presentations of dystonia are associated with psychiatric abnormalities. For instance, alcohol addiction, anxiety, depression and, particularly, obsessive-compulsive disorder have been associated with DYT11 (myoclonus-dystonia). Interestingly, patients present with more compulsions than obsessive symptoms ${ }^{22}$. Recently, mild executive dysfunction was also described as part of the clinical spectrum of DYT $11^{22}$. Mood disorders and psychoses have a higher prevalence in patients with rapid onset dystonia-parkinsonism (DYT12) than in non-mutant carriers $^{23,24}$. Psychiatric non-motor features are also found in sporadic forms of primary dystonia. In one study comparing primary dystonia patients (blepharospasm and cervical dystonia) with matched controls, it was demonstrated that anxiety, panic disorder, agoraphobia, obsessive-compulsive disorder, alcohol abuse and drug dependence were more common in the patients with dystonia ${ }^{25}$. Moreover, these psychiatric disorders frequently preceded the movement disorder. There is still debate whether these symptoms result from dysfunction of the brain or are a psychological reaction to a disabling condition. The onset of the psychiatric abnormalities before the development of motor findings of dystonia suggest the former hypothesis is true. Studies of cognition in dystonia have yielded conflicting results. A recent investigation of non-depressed adult-onset primary cranial-cervical dystonia patients showed differences in working memory, processing speed, visual motor ability and short-term memory. The impairment did not correlate with the disease severity or duration of dystonia ${ }^{26}$. These findings could be partially explained by the involvement of the fronto-striatal circuits previously demonstrated by voxel-based morphometry studies $^{26}$. Further studies are necessary to confirm these data and also to assess whether these abnormalities are persistent or even progressive. From a clinical perspective, the impression is that the majority of patients with primary dystonia do not have meaningful cognitive abnormalities ${ }^{25,26}$.

\section{ETIOLOGY}

The etiology of primary dystonia is assumed to be a complex combination of intrinsic metabolic properties, environmental and genetic factors ${ }^{27,28}$.

\section{Risk factors}

In a recent study from Queensland, Australia, several putative associations have been made with isolated idiopathic dystonias. Anxiety disorders, tremor, cigarette smoking and head injuries with a loss of consciousness were statistically associated with increased risk of developing dystonia ${ }^{27}$. Scoliosis and soft tissue trauma appear to increase the risk of cervical dystonia in genetically predetermined individuals $^{28,29}$. Sunlight exposure has been linked to a higher risk factor for the development of blepharospasm. It has been hypothesized that high insolation induces excessive blinking and this overuse results in sustained orbicularis oculii spasms $^{30}$. Repetitive highly-skilled manual performance may be associated with the development of focal hand dystonia ${ }^{31}$. Taken together these findings suggest that overuse of a body part could play a role in the development of task-specific dystonia in a predisposed individual. Aberrant neuronal plasticity of a motor learned program by repeated practice holds an 
important clue to the etiopathology of dystonia ${ }^{31}$. Although controversial, peripheral neuro-musculoskeletal injury appears also to be a risk factor for task specific dystonias. A possible explanation could be overcompensation to the deficit generating a lack of inhibition leading to dystonia ${ }^{32}$.

\section{Pathophysiology}

The pathophysiology of dystonia lies in the basis of lack of inhibition. Basal ganglia filter and modulate inputs to improve the precision of fine movements. The failure of surrounding suppression is probably related to deficient inhibition by basal ganglia gabaergic interneurons and output $^{31}$. One emerging theory is that sensorimotor systems have Hebian-like plasticity ${ }^{33}$. In a dystonic endophenotype, the summation of abnormal sensorimotor plasticity and the inability to control homeostatic mechanisms results in a chaotic reorganization of sensory-motor maps. For instance, an abnormal plastic change occurs without a downregulation to inhibit it ${ }^{34}$.

It is speculated that the cerebellum is also involved in the deficit of sensorimotor integration presented in dystonia. The cerebellum might process afferent proprioceptive information and modify the threshold of the somatosensory cortex through the cerebello-thalamo-cortical loop. It could also influence the cortex plasticity ${ }^{35}$.

\section{Genetic factors}

There is a relatively large body of knowledge of genetic factors in dystonia. Since the first description, in 1997, of a gene linked to familial dystonia, DYT1, several other genes have been reported either by linkage analyses or high throughput assays. This has led to new insights of the cellular pathways associated with this neurological dysfunction ${ }^{6}$.

The practitioner faces the daunting task of how to correlate the large number of dystonia-related genes with clinical features. To overcome this challenge, a wide-ranging algorithm, constructed on the clinical basis for the diagnosis of hereditary dystonias in which genetic testing is possible, was created (Figure 3). In a didactic and pragmatic approach, dystonia was categorized into pure dystonia, dystonia associated with other movement disorders or paroxysmal dystonias ${ }^{36}$.

To make a specific diagnosis where dystonia is the sole neurologic manifestation, one should take into consideration the age at onset, spread pattern and involvement of cranial and laryngeal muscles. DYT1, the most common hereditary dystonia, is also the most common cause of pure genetic dystonias ${ }^{4}$. Patients usually have childhood or adolescence onset, with initial focal involvement of one limb (usually lower) spreading to other limbs and muscles, becoming generalized but sparing the larynx and cranial muscles. Although phenotypically similar to DYT1, DYT6 onset is later (average 19 years of age), typically in the cranial and cervical muscles, and those who have limb onset (often arms) later develop cranial or cervical dystonia. In a patient with focal, segmental or generalized dystonia with cranial muscle involvement, DYT6 is the most likely the cause ${ }^{37}$. However, if negative, the next gene that should be tested is DYT1. It is very important to emphasize that DYT1 and DYT6 have an incomplete penetrance (30\% and $60 \%$, respectively), which can easily lead to misinterpretation as sporadic, or autosomal recessive inheritance. The same mutation in DYT6, even within a family, can present with different phenotypes ${ }^{38}$.

Isolated craniocervical dystonia can be related to two recently-described forms of dystonia: DYT23 and DYT24. The former was described in a family of German origin and is still to be confirmed ${ }^{39}$. DYT24 was described in a British family and three unrelated patients. The patients usually present with adult-onset dystonia involving the neck and/or face. DYT27 was recently described as a cause of segmental dystonia in three German families. The patients present with cranial, laryngeal and segmental dystonia with cervical, upper limbs and trunk involvement. The mode of inheritance is recessive. DYT25 is another dystonia that can overlap clinically with DYT1 and DYT6. It may present as focal, segmental or generalized dystonia, with onset mostly in adulthood (mean age 31 years) ${ }^{40}$. DYT2 is another cause of recessive segmental dystonia, often with slow progression to generalized dystonia, therefore also overlapping with DYT1 and DYT6. Its causative gene was only recently described (COL6A3) and it is related to Bethlem myopathy ${ }^{41}$. "Whispering dysphonia" (adductor spasmodic dysphonia, DYT4) was described in a large family in North Queensland, Australia in 1985. Dysphonic symptoms may improve with alcohol. Patients typically have a thin body and face, hollowed cheeks and a bradykinetic tongue as well as psychiatric symptoms (anxiety, aggressive behavior and alcohol abuse). Dystonia progresses to the generalized form and patients often exhibit a peculiar hobby horse gait with ataxia. Recently the putative gene of this condition has been described at 19p13.3 (TUBB4) ${ }^{42}$. Other primary dystonias, whose genes have not been identified yet, are DYT7, DYT13, and DYT17. With the exception of DYT7, whose clinical features resemble DYT23 and DYT24, these dystonias have a phenotype overlapping with DYT1 and $6^{37,38}$.

In the case of dystonia associated with other movement disorders, the phenomenology guides us through the diagnosis. If there is myoclonus, DYT11 or DYT26 are probably the cause. In DYT11, myoclonus, highly responsive to alcohol, is usually a significant symptom and the dystonic manifestation is often represented by spasmodic torticollis or writer's cramp ${ }^{43}$. Occasionally, dystonia may be the only manifestation of the disease and may precede myoclonus. A high incidence of psychiatric disturbances is described in DYT11. Otherwise, in DYT27 patients do not present with psychiatric disturbances or myoclonus responsive to alcohol, as frequently observed in DYT11. Myoclonus-dystonia has genetic heterogeneity and the known causative loci are DYT11, DYT15 and DYT26 $6^{44,45}$. Putative genes were described 


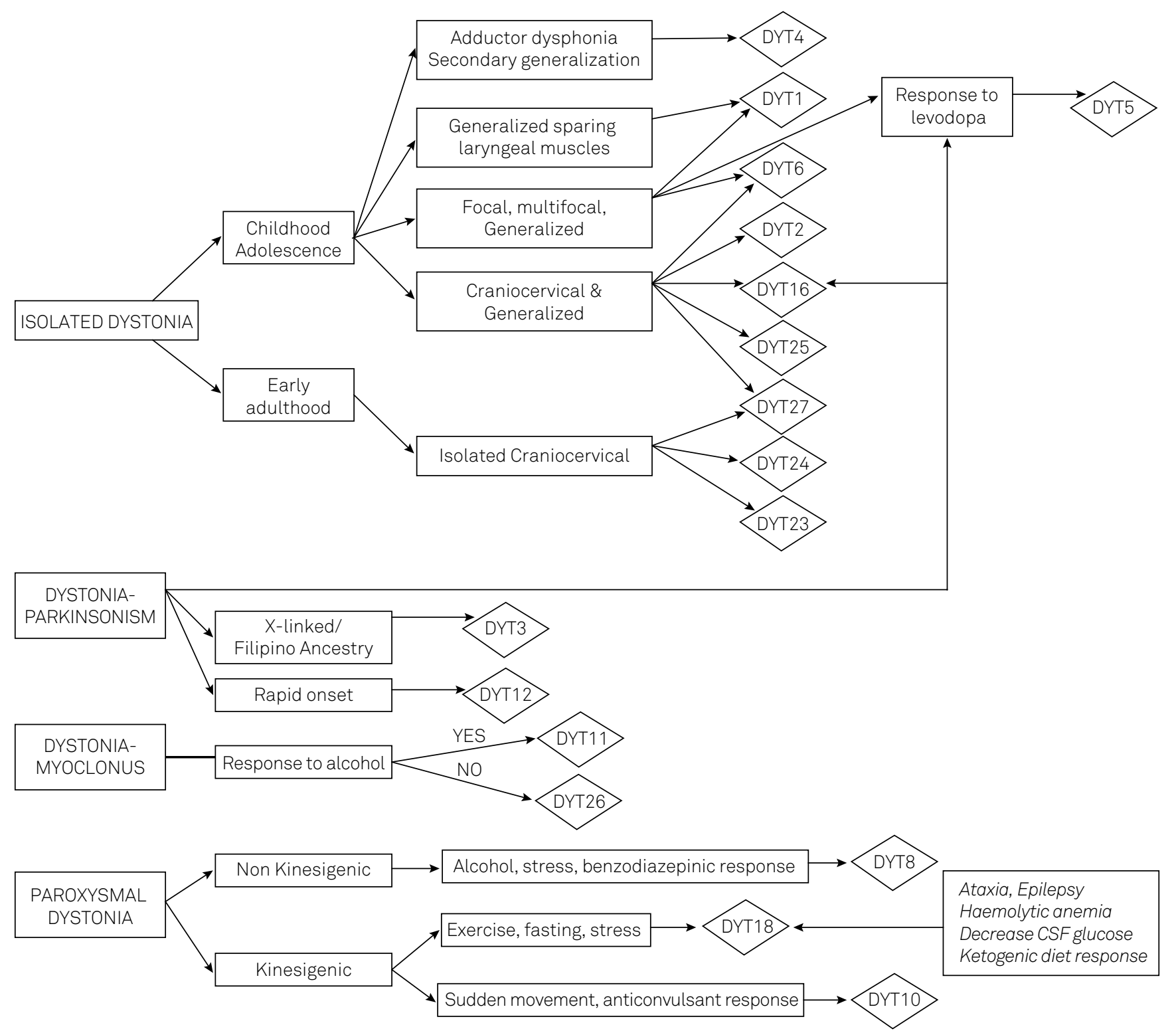

Figure 3. Algorithm for the diagnosis of hereditary dystonias.

only in DYT11 and DYT27, the encoding proteins of which are, respectively, epsilon sarcoglycan and potassium channel tetramerization domain-containing protein $17^{44,45}$.

In the case of parkinsonism associated with dystonia, levodopa response, mode of inheritance and mode of onset provide clues to the correct etiologic diagnosis. If dystonia-parkinsonism responds to levodopa, DRD is probably the cause. Two genes are related to DRD: GCH1 and $\mathrm{TH}^{46,47}$. Mutations of GCH1 (GTP cyclohydrolase 1) are transmitted in an autosomal dominant manner (DYT5a). Patients may develop worsening of the symptoms at the end of the day and there is complete remission of symptoms after administration of low doses of levodopa ${ }^{48}$. Importantly, unlike individuals with PD, patients with DYT5a usually do not develop complications from the chronic use of levodopa. The phenotype spectrum of CGH1 mutations has expanded and includes spasticity and spastic paraplegia. DYT5b is the other gene encoding mutation of the tyrosine hydroxylase enzyme. It causes the recessive Segawa syndrome, also characterized by marked improvement with administration of levodopa, and diurnal fluctuation. However, unlike the dominant form, patients usually present with motor and speech delay, hypotonia, encephalopathy, ataxia, and autonomic failure, as well as changes of the sleep-awake cycle ${ }^{47}$. In a dystonia-parkinsonism patient not responsive to levodopa with a recessive mode of inheritance, DYT16 should be considered. Some DYT16 patients may not exhibit parkinsonism but, instead, present with pure generalized dystonia with predominantly axial features involving speech and a sardonic smile ${ }^{49}$. If a pedigree shows only affected males, X-linked inheritance is likely. The X-linked dystonia occurs predominantly in Filipino families from the Panay Island. In addition to parkinsonism, myoclonus, chorea and tremor were also described ${ }^{48}$. 
The onset of dystonia can be quite informative about the underlying genetic cause as well. DYT12 typically has an acute onset (minutes to 30 days) after a stressful event, with a rapid craniocaudal evolution and prominent bulbar parkinsonism, characterized by bradykinesia and postural instability with no tremor. These individuals fail to respond to levodopa. There are also reports of patients with a less abrupt mode of onset ${ }^{51}$.

If dystonia is paroxysmal, it is important to distinguish between kinesigenic and non-kinesigenic forms. Either prolonged exercise or sudden movements can precipitate kinesigenic dyskinesia. In the former, paroxysmal exercise-induced dyskinesia (DYT18) is likely the cause. This condition has a strong association with epilepsy, mostly absence seizures, as well as ataxia, mild cognitive impairment, hemolytic anemia, reticulocytosis and hypoglycorrhachia ${ }^{52,53}$. Attacks usually last 10-40 minutes. It is also named GLUT1 deficiency syndrome type 2, which represents the less severe phenotype. A ketogenic diet can help some patients ${ }^{53}$. GLUT1 deficiency syndrome results from the impairment of glucose transport to the brain. The classical form includes epilepsy, developmental delay, acquired microcephaly, hypotonia, spasticity and movement disorders ${ }^{53}$. Paroxysmal movement disorders, alternating hemiplegia, ataxia and migraine have broadened the phenotype. Another form of exercise-induced dystonia is DYT9. In addition to paroxysmal movements, patients usually have progressive spastic paraparesis, cognitive decline, epilepsy, migraine and episodic ataxia. Alcohol, caffeine and stress can also trigger symptoms. Improvement with acetazolamide is reported in some patients ${ }^{54}$. There is genetic heterogeneity in kinesigenic dystonia, with many patients testing negative for currently known genes.

If sudden movements induce dystonia, DYT10 is the most probable cause. The attacks last a few seconds (usually less than a minute), without loss of consciousness, with good response to antiepileptic drugs. Seizures (benign childhood epilepsy) are common ${ }^{55}$.

In non-kinesigenic paroxysmal dyskinesia, DYT8, the attacks can be precipitated by alcohol, fatigue, hunger, stress and caffeine. They last from minutes to hours, occurring several times a week with good response to benzodiazepines and sleep benefit ${ }^{56}$. All these paroxysmal dystonias have autosomal dominant inheritance.

\section{Protein Functions and Interactions}

An interesting growing field of knowledge is the interaction between proteins linked to hereditary dystonia (Figure 4). The first described protein related to dystonia is torsinA, a putative member of AAA+ protein superfamily (ATPases associated with diverse cellular activities). AAA+ ATPases work as "molecular machines" with chaperone function, ultimately guaranteeing multimerization, protein folding efficiency and preventing abnormal aggregation ${ }^{57,58,59}$. TorsinA localizes in the endoplasmic reticulum (ER) lumen through its C-terminal domain. The hydrophobic N-terminal domain is thought to be linked to the ER membrane and nuclear envelope (NE) through another membrane protein, possibly LULL1 ${ }^{59}$. The critical substrate for the protein related to DYT1 function has not been clearly established. Several studies demonstrate that it interacts with other proteins (LAP1, LULL1, KLC1, vimectin, snapin, nesprin, actin, cine$\sin ^{59-62}$, organizing both the NE and ER. This function suggests that it plays a role in secretory pathways and synaptic recycling. TorsinA can modulate stress response either acting as a classical chaperone impairing the cell's ability to clear missfolded proteins or modulating the response of cells to ER stress $^{63}$. TorsinA mutation (an inframe GAG deletion) causes a loss of a glutamic acid near the carboxyl terminus, resulting in structural change of protein and redistribution of torsinA from the ER to the NE, which leads to a loss of function and modification of torsinA-mediated pathways. Mutated torsinA has other possible mechanisms: its altered form could modify its own oligomerization and degradation, since the site of the mutation is located within the C-terminal AAA+ subdomain, which supports oligomerization of other AAA+ ATPases. In addition, the mutated form appears to interact with tyrosine hydroxylase (DYT5b) while the wild type does not. Such interaction results in an enhancement of tyrosine hydroxylase activity and possibly a disruption of the regulatory mechanisms of tyrosine hydroxylase ${ }^{64}$. Dystonia might be explained by a functional imbalance of neuronal activity. DYT1 mutation could affect the protein process in dopaminergic neurons of the substantia nigra, which have the highest levels of torsinA message expression in the human brain ${ }^{65}$.

DYT6 was described in two nonrelated Mennonite families in 1997 and the locus was narrowed down in 2007 with a third Amish-Mennonite family; and, two years later, Thanatos-associated protein (THAP1) gene mutations were described as responsible for DYT6 dystonia ${ }^{37,66}$. THAP1 has a conserved protein motif, the THAP domain, that is a zincdependent DNA binding domain located at N-terminus of the protein. Human THAP1 protein may function as sequence-specific DNA binding factors with roles in proliferation, apoptosis, cell cycle and transcriptional regulation. It is a nuclear proapoptotic factor that enhances apoptosis via tumor necrosis factor (TNF-alpha) and interacts with another proapoptotic factor, prostate-apoptosis-response-4 (Par4) ${ }^{67}$. Par4 is a well-known proapoptotic gene and functions as a transcriptional repressor. Cells are usually resistant to apoptosis by Par4; however, they are greatly sensitized by Par4 in neurodegenerative diseases. Par4 can also act as a regulator of D2R (dopamine receptor subtype 2), interfering with the inhibitor input to adenylate cyclase. It is not yet clear whether and how the interaction of THAP1 with Par-4 can affect the ability of Par-4 to bind D2R. Some studies have demonstrated that THAP proteins may play a role in the control of cell proliferation and cell-cycle progression ${ }^{68}$. THAP1 regulates cell proliferation through modulation of target genes 


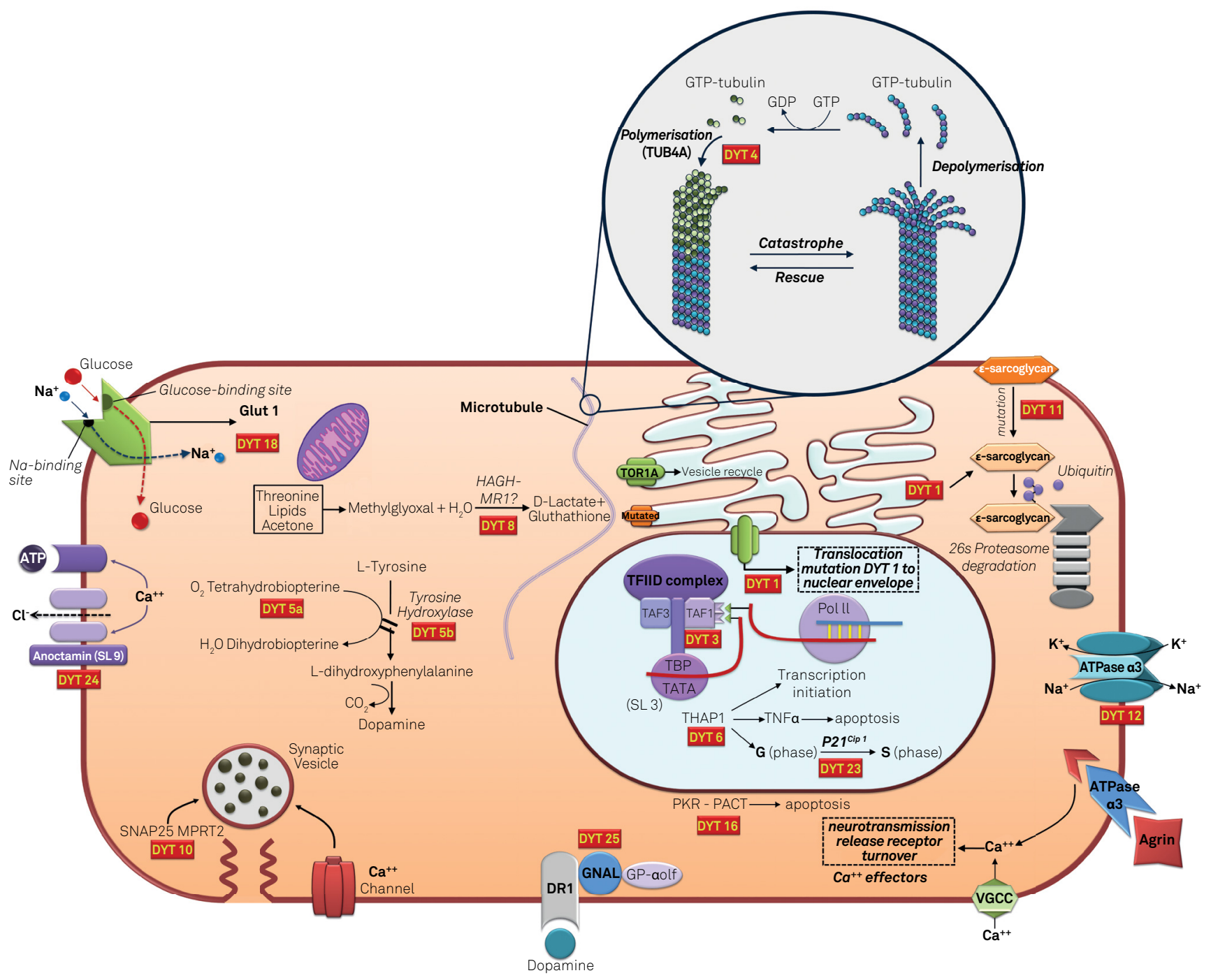

Figure 4. The dystonic cell.

such as RRM1, a gene required in the S phase of DNA synthesis. It remains to be determined, however, how these cell abnormalities lead to dystonic movements.

DYT3 dystonia is caused by a specific retrotransposon insertion in intron 32 of the TAF1 gene. This is associated with deregulation of the cell cycle. TAF1 (TATA-binding protein-associated factor-1 gene or DYT3) is part of the transcriptional complex (TFIID), which is a DNA binding complex required for RNA polymerase II, mediates transcription of many protein-encoding genes and also induces the G1/S phase progression. DYT3 patient postmortem brain studies have shown decreased expression of TAF1 and dopamine receptor D2 gene ${ }^{69}$. Once more, it is unclear how these changes result in dystonia.

A surprising link was found between THAP1 and TAF-1 (DYT3): both share protein partners (HCF-1, a cell cycle factor and potent transcriptional coactivator, and OGT, an enzyme that mediates O-GlcNAcylation of nucleocytoplasmic proteins $)^{70}$. This study raised the possibility that OGT and glucose metabolism may play a role in the pathophysiology of both DYT6 and DYT3 dystonias. There is another possible link between DYT1 and DYT6: THAP1 (DYT6) may regulate transcription of torsinA (DYT1) as a transcriptional repressor. DYT6 mutants may lead to an enhancement of torsinA (DYT1) expression. TorsinA, in high levels, has been proven to be deleterious to neuron cells, thus leading to loss of function and then to dysfunction ${ }^{71}$. THAP1 may regulate other potential gene targets, which could also influence the different phenotype between DYT1 and DYT6.

A mutation in the PRKRA gene (protein kinase, interferon-inducible double stranded RNA dependent activator, DYT16) was first described in three unrelated Brazilian families ${ }^{50}$. The same mutation (p.P222L) was found to segregate with the disease in a Polish family with dystonia ${ }^{72}$. DYT16 encodes PKR, an interferon-induced serine/threonine kinase expressed ubiquitously. PKR has been consistently implicated in 
several diverse cellular functions such as growth regulation, cellular stress response, apoptosis, differentiation and signaling pathways ${ }^{73,74}$.

Stress induces the phosphorylation of PACT. PACT binds to PKR at a double strand RNA (dsRNA) binding motif leading to PKR activation. Activated PKR phosphorylates translation initiation factor (eIF2 $\alpha$, which is responsible for the inhibition of protein synthesis and apoptosis. Recent studies with lymphoblast cell lines comparing activities of wild type and P222L mutants demonstrated that the homozygous mutant activates PKR with slower kinetics albeit more robustly and for longer duration. Also, in mutants the affinity interactions PACT-PACT dimer and PACT-PKR are enhanced, intensifying PKR activation resulting in cellular death by apoptosis ${ }^{75}$. The mechanisms of the increment in apoptosis and dystonia are uncertain although it is reasonable to assume that the stress response is a common pathway in DYT1, DYT6 and DYT $16^{63}$.

\section{TREATMENT}

While the pathogenesis of dystonia still needs to be unraveled, pharmacological treatment options are limited to symptomatic relief of the abnormal movement. Anticholinergics, GABA agonists, dopamine precursor, dopamine agonists, dopamine antagonists and also MAO depletors have been used for treatment of several types of dystonia ${ }^{76}$. We performed a literature review based on MEDLINE and the Cochrane Library to identify publications on pharmacological treatment (not including botulinum toxin injections) published between 1973 and 2015. Of note, there is only one evidence-based review addressing the issue ${ }^{77}$. As shown in Table 2, there are 13 randomized double blind placebo controlled trials (RCT). Trihexyphenidyl is the only proven effective anticholinergic in a randomized doubleblinded placebo controlled crossover trial (RCCT) for generalized and segmental dystonia. The benefits for cranial or focal dystonias were uncertain (Table 2). In a study of patients with cerebral palsy, trihexyphenidyl did not demonstrate benefits in any outcome measure. Regarding dopamine precursors, a recent trial with levodopa failed to demonstrate a better upper limb functional performance in patients with dystonic cerebral palsy. Other than this study, levodopa has never been tested in a RCT for generalized or focal dystonias. Nevertheless, clinical experience shows that levodopa has a dramatic response in DRD. For this reason, a trial of levodopa in generalized dystonia is mandatory to exclude DRD in all patients with early onset dystonia. Lisuride, a dopamine agonist, was tested in two trials with inconsistent effects in both generalized and focal dystonias. Tetrabenazine was tested only once in a RCCT and was shown to be effective in all four tardive dyskinesias, four of six Meige syndromes and five of six other dystonias. Intrathecal baclofen injection has been tested in a placebo-controlled study in secondary dystonia due to traumatic brain injury with reduction in spasticity and dystonia; there are no results for other RCCT studies. The only RCT evaluating benzodiazepines in dystonias studied clonazepam in tardive dyskinesia. In this small group of patients, $35 \%$ of the 19 patients with a predominantly dystonic clinical picture experienced decrease of dystonia severity. Apomorphine, bromocriptine in high doses $(18-150 \mathrm{mg} / \mathrm{d}$ ), oral baclofen, clonazepam and dopamine antagonists have been used in uncontrolled studies, case reports, case series or open trials with unproven effects ${ }^{77-94}$.

Some recent experimental studies have focused on the effect of antimuscarinic therapy in dystonia. In a DYT1 mice model, high-frequency stimulation in striatal spiny neurons failed to induce long-term depression, whereas low-frequency stimulation did not depotentiate corticostriatal synapses in very specific brain areas ${ }^{95}$. Also, cholinergic interneurons responded abnormally to D2R activation with potentiation rather than inhibition ${ }^{95}$. Anticholinergic drugs with selective muscarinic receptor antagonism are able to offset the synaptic plasticity deficit ${ }^{96}$. In summary, there is a rationale for the use of anticholinergic agents in the management of dystonia.

Botulinum toxin therapy revolutionized the treatment of focal dystonias. It acts by inducing chemodenervation of the affected muscles. Currently, several botulinum toxin formulations are available and widely used in the treatment of dystonias, and are the first line treatment for focal and segmental dystonias ${ }^{97}$. A recent evidence-based review of botulinum toxin in movement disorders supports the use of botulinum toxin in several types of dystonias. For blepharospasm, the recommendation is level A for onabotulinumtoxinA (Botox') (onaA) and incobotulinumtoxinA (Xeomin) (incoA); level B for abobotulinumtoxinA (Dysport)(aboA) and level U for rimabotulinumtoxinB (rimaB). In cervical dystonias, the evidence supports level A for all formulations. In limb dystonias, the recommendation is level $\mathrm{B}$ for aboA, onaboA and level $U$ for incoA and rimaB. For oromandibular dystonia the recommendation is level $\mathrm{C}$ for aboA and onaA. For adductor dysphonia evidence supports level $\mathrm{C}$ for onaA and level $\mathrm{U}$ for other formulations ${ }^{98}$.

Regarding surgical treatment, both pallidotomy and thallidotomy provide mild to moderate benefits but are often associated with many complications, particularly dysarthria and dysphagia. Because of the limited efficacy and significant complications, these treatments are no longer used. Deep brain stimulation (DBS) for dystonia has been performed since 1977 for cervical dystonia and since 1999 for generalized dystonia $^{99,100}$. Internal globus pallidus (GPi) is the target in class I and II studies, which are level 1 evidence ${ }^{101}$. Deep brain stimulation is considered markedly effective for generalized and segmental dystonias. Some factors are predictive for a good outcome: younger age at surgery $(<21 \mathrm{y})$ and shorter duration of symptoms $(<15 \mathrm{y})$. There is also data suggesting that DYT1 mutation carriers have a consistently good response to GPi DBS ${ }^{102}$. However, although one study did not show decreased efficacy 
Table 2. Controlled studies in dystonia since 1973.

\begin{tabular}{|c|c|c|c|c|c|}
\hline Study & Drug & Design & $\mathrm{n} /$ time & Outcome & Result \\
\hline Jankovic, $1982^{77}$ & $\begin{array}{c}\text { Tetrabenazine in } \\
\text { hyperkinetic movement } \\
\text { disorder }\end{array}$ & RDBPCCT & $19 / 3 w k$ & $\begin{array}{l}\text { Clinical } \\
\text { assessment }\end{array}$ & $\begin{array}{c}\text { Improvement in all } 4 \text { tardive } \\
\text { dyskinesia, } 4 \text { of } 6 \text { Meige, } 5 \text { of } 6 \\
\text { other dystonias }\end{array}$ \\
\hline Lang et al., $1982^{78}$ & $\begin{array}{l}\text { IV Atropine, Benztropine } \\
\text { and Chlorpheniramine in } \\
\text { focal dystonias }\end{array}$ & $\begin{array}{l}\text { Drug versus } \\
\text { placebo }\end{array}$ & 20 & $\begin{array}{l}\text { Clinical } \\
\text { assessment }\end{array}$ & No improvement \\
\hline Nutt et al., $1984^{79}$ & $\begin{array}{c}\text { Trihexyphenydil, } \\
\text { Tridihexethyl in cranial } \\
\text { dystonia }\end{array}$ & RDBPCCT & $9 / 6 w k$ & $\begin{array}{c}\text { Clinical } \\
\text { assessment }\end{array}$ & Only one patient improved \\
\hline Quinn et al., $1985^{80}$ & $\begin{array}{c}\text { Lisuride in several dystonia } \\
\text { types }\end{array}$ & $\mathrm{RDBPCCT}^{*}$ & $42 / 2 w k$ & $\begin{array}{c}\text { Clinical } \\
\text { assessment }\end{array}$ & 8 patients improved \\
\hline Nutt et al., $1985^{81}$ & Lisuride in focal dystonia & RDBPCCT & $9 p t / 12 w k$ & $\begin{array}{c}\text { Clinical } \\
\text { assessment }\end{array}$ & $\begin{array}{l}\text { Mild and transient improvement } \\
\text { in } 6 \text { patients }\end{array}$ \\
\hline Newman et al., $1985^{82}$ & Bromocriptine & RDBPCCT & $13 \mathrm{pt} / 7 \mathrm{wk}$ & $\begin{array}{l}\text { Clinical } \\
\text { assessment }\end{array}$ & $\begin{array}{c}7 \text { improved mores than } 10 \%, 2 \\
\text { worsend and } 5 \text { had disability } \\
\text { improvement }\end{array}$ \\
\hline Burke et al., $1986^{83}$ & Trihexyphenydil & RDBPCCT & $31 / 36 w k$ & $\begin{array}{l}\text { Fahn Marsden } \\
\text { scale }\end{array}$ & $\begin{array}{c}\text { Significant response in } 71 \% \text { of } \\
\text { patients; } 42 \% \text { dramatic response } \\
\text { after } 2,4 \text { years }\end{array}$ \\
\hline Carella et al., $1986^{84}$ & Gamma-vynil Gaba & RCCT & $6 / 2 w k$ & $\begin{array}{l}\text { Dystonia severity } \\
\text { scale, dystonia } \\
\text { disability scale and } \\
\text { dystonia muscle } \\
\text { assessment }\end{array}$ & No benefits \\
\hline Thaker el al., $1990^{85}$ & Clonazepam & RCCT & 19/12 wk & Dyskinesia rating & $\begin{array}{c}\text { Improvement (35\% decrease) } \\
\text { especially in dystonic prominent } \\
\text { patients }\end{array}$ \\
\hline Brans et al., $1996^{86}$ & $\begin{array}{l}\text { Botulinun toxin } \mathrm{X} \\
\text { trihexyphenidyl in } \mathrm{CD}\end{array}$ & RCT & $66 / 12 w k$ & TWTRS, Tsui scale & $\begin{array}{c}\text { BTA is more effective than } \\
\text { trihexyphenidil with less side } \\
\text { effects }\end{array}$ \\
\hline Ransmayr et al., $1988^{87}$ & $\begin{array}{l}\text { IV Biperiden, clonazepam, } \\
\text { haloperidol and lisuride } \\
\text { in Meige }\end{array}$ & PCT & 15 & $\begin{array}{l}\text { Clinical } \\
\text { assessment }\end{array}$ & $\begin{array}{l}\text { Improvement with IV clonazepan } \\
\text { and biperiden }\end{array}$ \\
\hline Braun et al., $1989^{88}$ & $\begin{array}{l}\text { SKF39393 (D1 dopamine } \\
\text { agonist) in hyperkinetic md }\end{array}$ & DBPCT & $3 / 2 w k$ & $\begin{array}{c}\text { Abnormal } \\
\text { involuntary } \\
\text { movement scale }\end{array}$ & No improvement \\
\hline Meythaler et al., $1999^{89}$ & $\begin{array}{l}\text { Intrathecal baclofen in } \\
\text { secondary dystonia due to } \\
\text { traumatic brain injury }\end{array}$ & PCT & 17/1 year & $\begin{array}{l}\text { Ashworth rigidity } \\
\text { scores, spasm } \\
\text { scores, and deep } \\
\text { tendon reflex score }\end{array}$ & $\begin{array}{l}\text { Reduction in spasticity and } \\
\text { dystonia }\end{array}$ \\
\hline Grañana et al., $1999^{90}$ & Diphenhydramine & RCT & $7 / 6 \mathrm{mo}$ & $\begin{array}{l}\text { University of } \\
\text { Columbia scale }\end{array}$ & $\begin{array}{l}\text { significant improvement, mild to } \\
\text { moderate side effects }\end{array}$ \\
\hline Rice et al., $2009^{91}$ & $\begin{array}{l}\text { Trihexyphenidyl in children } \\
\text { with cerebral palsy }\end{array}$ & RCCT & $16 / 28 w k$ & $\begin{array}{l}\text { Barry-Albright } \\
\text { Dystonia scale; } \\
\text { Quality of Upper } \\
\text { Extremity Skills } \\
\text { Test, Canadian } \\
\text { Occupational } \\
\text { Performance } \\
\text { Measure, and Goal } \\
\text { Attainment Scale }\end{array}$ & no significant effect \\
\hline Zadikoff et al., $2011^{92}$ & Dronabinol in CD & $\mathrm{RCCT} *$ & $9 / 8 w k$ & $\begin{array}{l}\text { TWSTRS, Visual } \\
\text { analogic scale } \\
\text { of pain, Global } \\
\text { impression of } \\
\text { change }\end{array}$ & no significant effect \\
\hline Bonouvrié et al., $2013^{93}$ & $\begin{array}{l}\text { Intrathecal baclofen in } \\
\text { dystonic cerebral palsy }\end{array}$ & $\begin{array}{l}\text { Multicenter } \\
\text { RDBCT }\end{array}$ & $30 / 3$ mo & $\begin{array}{l}\text { Goal Attainment } \\
\text { Scaling }\end{array}$ & no results yet \\
\hline Pozin et al., $2014^{94}$ & $\begin{array}{l}\text { Levodopa in dystonic } \\
\text { cerebral palsy }\end{array}$ & RCCT & $9 p t / 2 w k$ & $\begin{array}{l}\text { Upper limb } \\
\text { functional } \\
\text { performance }\end{array}$ & no response \\
\hline
\end{tabular}

RDBPCCT: Randomized, double blinded, placebo controlled crossover trial; RCCT: Randomized, double blinded, placebo controlled trial; RCT: randomized controlled trial; PCT: Placebo-controlled trial; wk: week; mo: months; CD: cervical dystonia. 
for up to 96 months in four patients, others have found progression of disability in eight patients with the need for new lead implantation. This led to significant improvement in four patients ${ }^{102,103}$. Regarding DYT6, Vidailhet et al. showed that the site of dystonia itself is a better predictor than genetic status but patients with spasmodic dysphonia and cranial involvement tend to have a limited response to $\mathrm{DBS}^{101}$. Individual cortical plasticity, fixed skeletal deformities, presence of myelopathy and placement of the electrodes have major influences on the outcome of surgery in both cervical and generalized dystonia. Finally, DBS is considered effective in myoclonus-dystonia (DYT11) and tardive dyskinesia ${ }^{101}$. The role of surgery in secondary dystonias (cerebral palsy, inherited metabolic disorders) is still debatable. One study of a small group of patients demonstrated that deep anterior cerebellar stimulation reduces spasticity and symptoms of secondary dystonia in cerebral palsy patients ${ }^{104}$. Other treatments have been studied for dystonia. Subthalamic nucleus stimulation and simultaneous GPi and subthalamic nucleus stimulation are emerging as promising in the surgical treatment of dystonia ${ }^{105}$. Apparently subthalamic nucleus stimulation does not impair working memory and attention, as has been reported in $\mathrm{PD}^{106}$. Patients should be aware of the risk of inherent complications of the surgery, such as stimulation-related dysarthria, parkinsonism, gait disorders and depression (including suicide attempts).

\section{COMMENTS}

The new definition of dystonia has created a conceptual framework that helps clinicians diagnose and classify different forms of dystonia. Nevertheless, clinical features remain the cornerstone of identification and differential diagnosis. With a few exceptions, ancillary tests, as well as neurophysiological studies, play a limited role in diagnosing dystonia. Dystonia is a syndrome, with clinical and etiological heterogeneity, probably with a final common pathway. It seems to be the resulting force of a complex network of genetic, epigenetic and environmental vectors. Penetrance is the result of adding individual vectors ${ }^{6,27,28,29,30}$.

Sensory abnormalities may drive dystonia, as well as somatosensory receptive fields being abnormally enlarged and disorganized in patients, with sensitive stimuli modulating dystonic movement. Motor and sensory systems mutually integrate and are abnormal in dystonia patients. The pathophysiology of dystonia lies in the lack of inhibition. Basal ganglia act as filtering and modulating inputs to improve the precision of fine movements. Abnormal dynamic homeostatic plasticity could be derived from an imbalance of dopaminergic and cholinergic reciprocal signaling in the striatum. The cerebellum may have a role in processing proprioceptive information, and regulating or integration and cortex plasticity through cerebello-thalamo-cortical loops ${ }^{33,34,35}$.

A great number of new monogenic dystonias have been described since the first gene was recognized in 1997. To date,
28 loci and 18 genes are known. Whole genome association studies, high-throughput sequencing and the loss of heterogeneity map have certainly accelerated the pace of gathering new information. In the last five years, eight genes related to familial dystonias have been described. All of them used new technology, mainly associated with linkage studies. Putative genes related to Mendelian forms of dystonia impair several pathways: chaperone-like (DYT1); apoptosis regulation (DYT6, DYT16); dopamine formation (DYT5a and b); synaptic transport (DYT10); synaptic recycling (DYT1); neuronal structure and transport (DYT4); transcription syndrome (DYT3, DYT6), redox status maintenance (DYT8); reduced D2 receptor availability (DYT1, DYT3, DYT6 and DYT11), transmembrane trafficking (DYT11), gradient ion maintenance (DYT12 and DYT24), glucose transport (DYT18), transduction signal pathway (DYT25), and cell cycle control (DYT23). None of these genes have shown an obvious common endpoint. Functional cell studies are emerging, especially shared partners among the described genes related to dystonia ${ }^{63}$.

A large bulk of knowledge about dystonia has been produced in recent years. Noticeably half of all PubMed publications are concentrated over the last 15 years. Non-motor features have increasingly been recognized as part of dystonia pathophysiology. In the next years, more studies in the field will clarify the spectrum of the dystonic syndromes. Deep brain stimulation has become a landmark in the treatment of generalized dystonias. New potential targets may arise in the near future. Modern next-generation sequencing technologies have increased awareness of new phenotypes in dystonia-related genes. For instance, different mutations in ATP1A3 genes can cause cerebellar ataxia, areflexia, pes cavus, optic atrophy and sensorineural hearing loss (CAPOS) syndrome; rapid onset dystonia-parkinsonism and alternating hemiplegia syndrome; and the same mutation can cause either rapid onset dystonia parkinsonism or alternating hemiplegia syndrome. Several theories such as environment, other modifying genes, non-coding variations and epigenetic factors explain the phenomenon but are still lacking confirmation. Possibly, a greater understanding of genetic supporters will overtake "the single gene disease concept" and this might lead to more individualized and rationale therapeutic targets providing patients with better treatment.

An improved understanding of pathogenetic pathways common to several dystonias could possibly lead to the discovery of new therapeutic targets to provide better symptomatic and, hopefully, etiological treatment. Further studies with more homogenous and bigger samples of patients with the same etiological category, and standardized examination, are needed to increase our knowledge of this cryptic disease.

\section{Acknowledgements}

Thiago Roberto Silva for the design of Figure 4. 
1. Lanska DJ. Chapter 33: the history of movement disorders. Handb Clin Neurol. 2010;95:501-46. doi:10.1016/S0072-9752(08)02133-7

2. Munts AG, Koehler PJ. How psychogenic is dystonia? Views from past to present. Brain. 2010;133(5):1552-64. doi:10.1093/brain/awq050

3. Fahn S. Concept and classification of dystonia. Adv Neurol. 1988;50:1-8. doi:10.1212/WNL.50.5_Suppl_5.S1

4. Ozelius LJ, Hewett JW, Page CE, Bressman SB, Kramer PL, Shalish $\mathrm{C}$ et al. The early-onset torsion dystonia gene (DYT1) encodes an ATP-binding protein. Nat Genet. 1997;17(1):40-8. doi:10.1038/ng0997-40

5. Broussolle E, Laurencin C, Bernard E, Thobois S, Danaila T, Krack P. Early ilustrations of geste antagoniste in cervical and generalized dystonia. Tremor Other Hyperkinet Mov (N Y) 2015:5:332-44. doi:10.7916/D8KD1X74

6. Bressman SB. Dystonia genotypes, phenotypes, and classification. Adv Neurol. 2004:94:101-7.

7. Albanese A, Bhatia K, Bressman SB, Delong MR, Fahn S, Fung VS et al. Phenomenology and classification of dystonia: a consensus update. Mov Disord. 2013;28(7):863-73. doi:10.1002/mds.25475

8. Albanese A, Lalli S. Is this dystonia? Mov Disord. 2009;24(12):1725-31. doi:10.1002/mds.22597

9. Loyola DP, Camargos S, Maia D, Cardoso F. Sensory tricks in focal dystonia and hemifacial spasm. Eur J Neurol. 2013;20(4):704-7. doi:10.1111/ene.12054

10. Sitburana O, Wu LJ, Sheffield JK, Davidson A, Jankovic J. Motor overflow and mirror dystonia. Parkinsonism Relat Disord. 2009;15(10):758-61. doi:10.1016/j.parkreldis.2009.05.003

11. Hallett M. Pathophysiology of writer's cramp. Hum Mov Sci. 2006;25(4-5):454-63. doi:10.1016/j.humov.2006.05.004

12. Sohn YH, Hallett M. Disturbed surround inhibition in focal hand dystonia. Ann Neurol. 2004;56(4):595-9. doi:10.1002/ana.20270

13. Cox BC, Cincotta M, Espay AJ. Mirror movements in movement disorders: a review. Tremor Other Hyperkinet Mov (NY). 2012;2. pii: tre-02-59-398-1. doi:10.7916/D8VQ31DZ

14. Castrioto A, Piscicelli C, Pérennou D, Krack P, Debû B. The pathogenesis of Pisa syndrome in Parkinson's disease. Mov Disord. 2014;29(9):1100-7. doi:10.1002/mds.25925

15. Doherty KM, van de Warrenburg BP, Peralta MC, Silveira-Moriyama L, Azulay JP, Gershanik OS et al. Postural deformities in Parkinson's disease. Lancet Neurol. 2011;10(6):538-49. doi:10.1016/S1474-4422(11)70067-9

16. Schrag A, Trimble M, Quinn N, Bhatia K. The syndrome of fixed dystonia: an evaluation of 103 patients. Brain. 2004;127(10):2360-72. doi:10.1093/brain/awh262

17. Erro R, Rubio-Agusti I, Saifee TA, Cordivari C, Ganos C, Batla A et al. Rest and other types of tremor in adult-onset primary dystonia.J Neurol Neurosurg Psychiatry. 2014;85(9):965-8. doi:10.1136/jnnp-2013-305876

18. Agnew A, Frucht SJ, Louis ED. Supine head tremor: a clinical comparison of essential tremor and spasmodic torticollis patients. J Neurol Neurosurg Psychiatry. 2012;83(2):179-81. doi:10.1136/jnnp-2011-300823

19. Quinn NP, Schneider SA, Schwingenschuh P, Bhatia KP. Tremor: some controversial aspects. Mov Disord. 2011;26(1):18-23. doi: $0.1002 / m d s .23289$

20. Mian OS, Schneider SA, Schwingenschuh P, Bhatia KP, Day BL. Gait in SWEDDs patients: comparison with Parkinson's disease patients and healthy controls. Mov Disord. 2011;26(7):1266-73. doi:10.1002/mds.23684

21. Batla A, Erro R, Stamelou M, Schneider SA, Schwingenschuh P, Ganos $C$ et al. Patients with scans without evidence of dopaminergic deficit: a long-term follow-up study. Mov Disord. 2014;29(14):1820-5. doi:10.1002/mds.26018
22. Peall KJ1, Smith DJ, Kurian MA, Wardle M, Waite AJ, Hedderly $T$ et al. SGCE mutations cause psychiatric disorders: clinical and genetic characterization. Brain. 2013;136(1):294-303. doi:10.1093/brain/aws308

23. Tricht MJ1, Dreissen YE, Cath D, Dijk JM, Contarino MF, Salm SM et al. Cognition and psychopathology in myoclonus-dystonia. J Neurol Neurosurg Psychiatry. 2012;83(8):814-20. doi:10.1136/jnnp-2011-301386

24. Brashear A, Cook JF, Hill DF, Amponsah A, Snively BM, Light L et al. Psychiatric disorders in rapid-onset dystonia-parkinsonism. Neurology. 2012;79(11):1168-73. doi:10.1212/WNL.0b013e3182698d6c

25. Fabbrini G, Berardelli I, Moretti G, Pasquini M, Bloise M, Colosimo $C$ et al. Psychiatric disorders in adult-onset focal dystonia: a case-control study. Mov Disord. 2010;25(4):459-65. doi:10.1002/mds.22983

26. Romano R, Bertolino A, Gigante A, Martino D, Livrea P, Defazio G. Impaired cognitive functions in adult-onset primary cranial cervical dystonia. Parkinsonism Relat Disord. 2014;20(2):162-5. doi:10.1016/j.parkreldis.2013.10.008

27. Newman JR, Boyle RS, O'Sullivan JD, Silburn PA, Mellick GD. Risk factors for idiopathic dystonia in Queensland, Australia. J Clin Neurosci. 2014;21(12):2145-9. doi:10.1016/j.jocn.2014.03.032

28. Molloy A, Kimmich O, Williams L, Butler JS, Byrne N, Molloy F et al. An evaluation of the role of environmental factors in the disease penetrance of cervical dystonia.J Neurol Neurosurg Psychiatry. 2015;86(3):331-5. doi:10.1136/jnnp-2014-307699

29. Defazio G, Abbruzzese G, Girlanda P, Buccafusca M, Currà A, Marchese R et al. Primary cervical dystonia and scoliosis: a multicenter case control study. Neurology. 2003;60(6):1012-15. doi:10.1212/01.WNL.0000049932.22065.60

30. Hutchinson M. Sun exposure is an environmental factor for the development of blepharospasm. J Neurol Neurosurg Psychiatry. 2016;87(4):420-4. doi:10.1136/jnnp-2014-310266

31. Lin PT, Hallett M. The pathophysiology of focal hand dystonia.J Hand Ther. 2009;22(2):109-14. doi:10.1016/j.jht.2008.10.008

32. Leijnse JN, Hallett M. Etiological musculo-skeletal factor in focal dystonia in a musician's hand: a case study of the right hand of a guitarist. Mov Disord. 2007;22:1803-8. doi:10.1002/mds.21636

33. Weise D, Schramm A, Stefan K, Wolters A, Reiners K, Naumann M et al. The two sides of associative plasticity in writer's cramp. Brain. 2006;1 29(10):2709-21. doi:10.1093/brain/awl221

34. Quartarone A, Morgante F, Sant'angelo A, Rizzo V, Bagnato $S$, Terranova $\mathrm{C}$ et al. Abnormal plasticity of sensorimotor circuits extends beyond the affected body part in focal dystonia.J Neurol Neurosurg Psychiatry. 2008;79(9):985-90. doi:10.1136/jnnp.2007.121632

35. Lehéricy S, Tijssen MA, Vidailhet M, Kaji R, Meunier S. The anatomical basis of dystonia: current view using neuroimaging. Mov Dis. 2013;28(7):944-57. doi:10.1002/mds.25527

36. Camargos S, Cardoso F. New algorithm for the diagnosis of hereditary dystonia. Arq Neuropsiquiatr. 2012;70(9):715-7. doi:10.1590/S0004-282X2012000900013

37. Saunders-Pullman R, Raymond D, Senthil G, Kramer P, Ohmann E, Deligtisch A et al. Narrowing the DYT6 dystonia region and evidence for locus heterogeneity in the Amish-Mennonites. Am J Med Genet A. 2007;143A(18):2098-105. doi:10.1002/ajmg.a.31887

38. Gajos A, Piaskowski S, Stawek J, Ochudło S, Opala G, Łobińska A et al. Phenotype of the DYT1 mutation in the TOR1A gene in a Polish population of patients with dystonia. A preliminary report. Neurol Neurochir Pol. 2007;41(6):487-94. 
39. Xiao J, Uitti RJ, Zhao Y, Vemula SR, Perlmutter JS, Wszolek ZK et al. Mutations in ClZ1 cause adult onset primary cervical dystonia. Ann Neurol. 2012;71(4):458-69. doi:10.1002/ana.23547

40. Fuchs T, Saunders-Pullman R, Masuho I, San Luciano M, Raymond D, Factor $S$ et al. Mutations in GNAL cause primary torsion dystonia. Nature Genet. 2013;45(1):88-92. doi:10.1038/ng.2496

41. Zech M, Lam DD, Francescatto L, Schormair B, Salminen AV, Jochim A et al. Recessive mutations in the $\alpha 3(\mathrm{VI})$ collagen gene COL6A3 cause early-onset isolated dystonia. Am J Hum Genet. 2015;96(6):883-93. doi:10.1016/j.ajhg.2015.04.010

42. Lohmann K, Wilcox RA, Winkler S, Ramirez A, Rakovic A, Park JS et al. Whispering dysphonia (DYT4 dystonia) is caused by a mutation in the TUBB4 gene. Ann Neurol. 2013;73(4): 537-545. doi:10.1002/ana.23829

43. Zimprich A, Grabowski M, Asmus F, Naumann M, Berg D, Bertram $M$ et al. Mutations in the gene encoding epsilon-sarcoglycan cause myoclonus-dystonia syndrome. Nat Genet. 2001;29(1):66-9. doi:10.1038/ng709

44. Kinugawa K, Vidailhet M, Clot F, Apartis E, Grabli D, Roze E. Myoclonus-dystonia: an update. Mov Disord. 2009;24(4):479-89. doi:10.1002/mds.22425

45. Mencacci NE, Rubio-Agusti I, Zdebik A, Asmus F, Ludtmann MH, Ryten $\mathrm{M}$ et al A missense mutation in KCTD17 causes autosomal dominant myoclonus-dystonia. Am J Hum Genet. 2015;96(6):938-47. doi:10.1016/j.ajhg.2015.04.008

46. Ichinose H, Ohye T, Takahashi E, Seki N, Hori T, Segawa M et al. Hereditary progressive dystonia with marked diurnal fluctuation caused by mutations in the GTP cyclohydrolase I gene. Nat Genet. 1994;8(3):236-42. doi:10.1038/ng1194-236

47. Lüdecke B, Dworniczak B, Bartholomé K. A point mutation in the tyrosine hydroxylase gene associated with Segawa's syndrome. Hum Genet. 1995;95(1):123-5. doi:10.1007/BF00225091

48. Nygaard TG, Marsden CD, Fahn S. Dopa-responsive dystonia: long-term treatment response and prognosis. Neurology. 1991;41(2 Pt 1):174-81. doi:10.1212/WNL.41.2_Part_1.174

49. Camargos S, Scholz S, Simón-Sánchez J, Paisán-Ruiz C, Lewis P, Hernandez D et al. DYT16, a novel young-onset dystonia-parkinsonism disorder: identification of a segregating mutation in the stress-response protein PRKRA. Lancet Neurol. 2008;7(3):207-15. doi:10.1016/S1474-4422(08)70022-X

50. Evidente VG, Advincula J, Esteban R, Pasco P, Alfon JA, Natividad FF et al. Phenomenology of "Lubag" or X-linked dystonia-parkinsonism. Mov Disord. 2002;17(6):1271-7. doi:10.1002/mds.10271

51. Aguiar PC, Sweadner KJ, Penniston JT, Zaremba J, Liu L, Caton M et al. Mutations in the $\mathrm{Na}(+) / \mathrm{K}(+)$-ATPase alpha-3 gene ATP1A3 are associated with rapid-onset dystonia parkinsonism. Neuron. 2004;43(2):169-75. doi:10.1016/j.neuron.2004.06.028

52. Weber YG, Storch A, Wuttke TV, Brockmann K, Kempfle J, Maljevic S et al. GLUT1 mutations are a cause of paroxysmal exertion-induced dyskinesias and induce hemolytic anemia by a cation leak.J Clin Invest . 2008;118(6):2157-68. doi:10.1172/JCI34438.

53. Brockmann K. The expanding phenotype of GLUT1-deficiency syndrome. Brain Dev. 2009;31(7):545-52. doi:10.1016/j.braindev.2009.02.008

54. Bhatia KP. The paroxysmal dyskinesias.J Neurol. 1999;246(3):149-55. doi:10.1007/s004150050325

55. Lee HY, Huang Y, Bruneau N, Roll P, Roberson ED, Hermann M et al. Mutations in the gene PRRT2 cause paroxysmal kinesigenic dyskinesia with infantile convulsions. Cell Reports. 2012;1(1):2-12. doi:10.1016/j.celrep.2011.11.001

56. Bruno MK, Lee HY, Auburger GW, Friedman A, Nielsen JE, Lang AE et al. Genotype-phenotype correlation of paroxysmal nonkinesigenic dyskinesia. Neurology. 2007;68(21):1782-9. doi:10.1212/01.wnl.0000262029.91552.e0
57. Granata A, Schiavo G, Warner TT. TorsinA and dystonia: from nuclear envelope to synapse. J Neurochem. 2009;109(6):1596-109. doi:10.1111/j.1471-4159.2009.06095.x

58. Chen P, Burdette AJ, Porter JC, Ricketts JC, Fox SA, Nery FC et al. The early-onset torsion dystonia-associated protein, torsinA, is a homeostatic regulator of endoplasmic reticulum stress response. Hum Mol Genet. 2010;19(18):3502-15. doi:10.1093/hmg/ddq266

59. Goodchild RE, Dauer WT. Mislocalization to the nuclear envelope: an effect of the dystonia-causing torsinA mutation. Proc Natl Acad Sci USA. 2004;101(3):847-52. doi:10.1073/pnas.0304375101

60. Granata A, Watson R, Collinson LM, Schiavo G, Warner TT. The dystoniaassociated protein torsinA modulates synaptic vesicle recycling.J Biol Chem. 2008;283(12):7568-79. doi:10.1074/jbc.M704097200

61. Burdette AJ, Churchill PF, Caldwell GA, Caldwell KA. The early-onset torsion dystonia-associated protein, torsinA, displays molecular chaperone activity in vitro. Cell Stress Chaperones. 2010;15(5):605-17. doi:10.1007/s12192-010-0173-2

62. Nery FC, Zeng J, Niland BP, Hewett J, Farley J, Irimia D et al. TorsinA binds the KASH domain of nesprins and participates in linkage between nuclear envelope and cytoskeleton. J Cell Sci. 2008;121(20):3476-86. doi:10.1242/jcs.029454

63. Bragg DC, Armata IA, Nery FC, Breakefield XO, Sharma N. Molecular pathways in dystonia. Neurobiol Dis. 2011;42(2):136-47. doi:10.1016/j.nbd.2010.11.015

64. O'Farrell CA, Martin KL, Hutton M, Delatycki MB, Cookson MR, Lockhart PJ. Mutant torsinA interacts with tyrosine hydroxylase in cultured cells. Neuroscience. 2009;164(3):1127-37. doi:10.1016/j.neuroscience.2009.09.017

65. Konakova M, Huynh DP, Yong W, Pulst SM. Cellular distribution of torsin A and torsin B in normal human brain. Arch Neurol. 2001;58(6):921-7. doi:10.1001/archneur.58.6.921

66. Fuchs T, Gavarini S, Saunders-Pullman R, Raymond D, Ehrlich ME, Bressman SB et al. Mutations in the THAP1 gene are responsible for DYT6 primary torsion dystonia. Nat Genet. 2009;41(3):286-8. doi:10.1038/ng.304

67. Roussigne M, Cayrol C, Clouaire T, Amalric F, Girard JP. THAP1 is a nuclear proapoptotic factor that links prostate-apoptosis-response-4 (Par4) to PML nuclear bodies. Oncogene. 2003;22(16):2432-42. doi:10.1038/sj.onc.1206271

68. Cayrol C, Lacroix C, Mathe C, Ecochard V, Ceribelli M, Loreau E et al. The THAP-zinc finger protein THAP1 regulates endothelial cell proliferation through modulation of pRB/E2F cell-cycle target genes. Blood. 2007;109(2):584-94. doi:10.1182/blood-2006-03-012013

69. Makino S, Kaji R, Ando S, Tomizawa M, Yasuno K, Goto S et al. Reduced neuron-specific expression of the TAF1 gene is associated with X-linked dystonia-parkinsonism. Am J Hum Genet. 2007;80(3);393-406. doi:10.1086/512129

70. Mazars R, Gonzalez-de-Peredo A, Cayrol C, Lavigne AC, Vogel JL, Ortega $\mathrm{N}$ et al. The THAP-zinc finger protein THAP1 associates with coactivator HCF-1 and O-GlcNAc transferase: a link between DYT6 and DYT3 dystonias. J Biol Chem. 2010;285(18):13364-71. doi:10.1074/jbc.M109.072579

71. Grundmann K, Reischmann B, Vanhoutte G, Hübener J, Teismann P, Hauser TK et al. Overexpression of human wildtype type torsinA and human Delta GAG torsinA in a transgenic mouse model causes phenotypic abnormalities. Neurobiol Dis. 2007;27(2):190-206. doi:10.1016/j.nbd.2007.04.015

72. Zech M, Castrop F, Schormair B, Jochim A, Wieland T, Gross N et al. DYT16 revisited: exome sequencing identifies PRKRA mutations in a European dystonia family. Mov Disord. 2014;29(12):1504-10. doi:10.1002/mds.25981

73. Huang $X$, Hutchins B, Patel RC. The C-terminal, third conserved motif of the protein activator PACT plays an essential role in the activation of double-stranded-RNA-dependent protein kinase (PKR). Biochem J. 2002;366(1):175-86. doi:10.1042/bj20020204 
74. Singh M, Castillo D, Patel CV, Patel RC. Stress-induced phosphorylation of PACT reduces its interaction with TRBP and leads to PKR activation. Biochemistry. 2011;50(21):4550-60. doi:10.1021/bi200104h

75. Vaughn LS, Bragg DC, Sharma N, Camargos S, Cardoso F, Patel RC. Altered activation of protein kinase PKR and enhanced apoptosis in dystonia cells carrying a mutation in PKR activator protein PACT. J Biol Chem. 2015;290(37):22543-57. doi:10.1074/jbc.M115.669408

76. Jankovic J. Medical treatment of dystonia. Mov Disord. 2013:28(7):1001-12. doi:10.1002/mds.25552

77. Jankovic J. Treatment of hyperkinetic movement disorders with tetrabenazine: a double-blind crossover study. Ann Neurol. 1982;11(1):41-7. doi:10.1002/ana.410110108

78. Lang AE, Sheehy MP, Marsden CD. Anticholinergics in adult-onset focal dystonia Can J Neurol Sci. 1982;9(3):313-9. doi:10.1017/S0317167100044139

79. Nutt JG, Hammerstad JP, Garmo P, Carter J Cranial dystonia: double-blind crossover study of anticholinergics. Neurology. 1984;34(2):215-7. doi:10.1212/WNL.34.2.215

80. Quinn NP, Lang AE, Sheehy MP, Marsden CD. Lisuride in dystonia. Neurology. 1985;35(5):766-9. doi:10.1212/WNL.35.5.766

81. Nutt JG, Hammerstad JP, Carter JH, Garmo PL. Lisuride treatment of focal dystonias. Neurology. 1985;35(8):1242-3. doi:10.1212/WNL.35.8.1242

82. Newman RP, LeWitt PA, Shults C, Bruno G, Foster NL, Chase TN et al. Dystonia: treatment with bromocriptine. Clin Neuropharmacol. 1985;8(4):328-33. doi:10.1097/00002826-198512000-00003

83. Burke RE, Fahn S, Marsden CD. Torsion dystonia: a double-blind, prospective trial of high-dosage trihexyphenidyl. Neurology. 1986;36(2):160-4. doi:10.1212/WNL.36.2.160

84. Carella F, Girotti F, Scigliano G, Caraceni T, Joder-Ohlenbusch AM, Schechter PJ. Double-blind study of oral gamma-vinyl GABA in the treatment of dystonia. Neurology. 1986;36(1):98-100. doi:10.1212/WNL.36.1.98

85. Thaker GK, Nguyen JA, Strauss ME, Jacobson R, Kaup BA, Tamminga CA. Clonazepam treatment of tardive dyskinesia: a practical GABAmimetic strategy. Am J Psychiatry. 1990;147(4):445-51 doi:10.1176/ajp.147.4.445

86. Brans JW, Lindeboom R, Snoek JW, Zwarts MJ, Weerden TW, Brunt ER, et al. Botulinum toxin versus trihexyphenidyl in cervical dystonia: a prospective, randomized, double-blind controlled trial. Neurology. 1996;46(4):1066-72. doi:10.1212/WNL.46.4.1066

87. Ransmayr G, Kleedorfer B, Dierckx RA, Poewe W, Kemmler GW, Gerstenbrand F. Pharmacological study in Meige's syndrome with predominant blepharospasm. Clin Neuropharmacol. 1988;11(1):68-76. doi:10.1097/00002826-198802000-00007

88. Braun A, Mouradian MM, Mohr E, Fabbrini G, Chase TN. Selective D-1 dopamine receptor agonist effects in hyperkinetic extrapyramidal disorders. J Neurol Neurosurg Psychiatry. 1989 ;52(5):631-5. doi:10.1136/jnnp.52.5.631

89. Meythaler JM, Guin-Renfroe S, Grabb P, Hadley MN. Long-term continuously infused intrathecal baclofen for spastic-dystonic hypertonia in traumatic brain injury: 1-year experience. Arch Phys Med Rehabil. 1999;80(1):13-9. doi:10.1016/S0003-9993(99)90301-5

90. Grañana N, Ferrea M, Scorticati MC, Díaz S, Arrebola M, Torres L et al. Beneficial effects of diphenhydramine in dystonia. Medicina (B Aires). 1999;59(1):38-42
91. Rice J, Waugh MC. Pilot study on trihexyphenidyl in the treatment of dystonia in children with cerebral palsy. J Child Neurol. 2009;24(2):176-82. doi:10.1177/0883073808322668

92. Zadikoff C, Wadia PM, Miyasaki J, Chen R, Lang AE, So J et al. Cannabinoid, CB1 agonists in cervical dystonia: failure in a phase Ila randomized controlled trial. Basal Ganglia. 2011;1(2)91-5. doi:10.1016/j.baga.2011.04.002

93. Bonouvrié LA, Becher JG, Vles JS, Boeschoten K, Soudant D, Groot $V$ et al. Intrathecal baclofen treatment in dystonic cerebral palsy: a randomized clinical trial: the IDYS trial. BMC Pediatr. 2013;13(1):175. doi:10.1186/1471-2431-13-175

94. Pozin I, Bdolah-Abram T, Ben-Pazi H. Levodopa does not improve function in individuals with dystonic cerebral palsy.J Child Neurol. 2014:29(4):534-7. doi:10.1177/0883073812473645

95. Maltese M, Martella G, Madeo G, Fagiolo I, Tassone A, Ponterio $G$ et al. A Anticholinergic drugs rescue synaptic plasticity in DYT1 dystonia: Role of M1 muscarinic receptors. Mov Dis. 2014;29(13):1655-65. doi:10.1002/mds.26009

96. Martella G, Maltese M, R, Schirinzi T, Madeo G, Sciamanna G al. Regional specificity of synaptic plasticity deficits in a knock-in mouse model of DYT1 dystonia. Neurobiol Dis. 2014;65:124-32. doi:10.1016/j.nbd.2014.01.016

97. Balash Y, Giladi N. Efficacy of pharmacological treatment of dystonia: evidence-based review including meta-analysis of the effect of botulinum toxin and other cure options. Eur J Neurol. 2004;11(6):361-70. doi:10.1111/j.1468-1331.2004.00845.x

98. Hallet M, Albanese A, Dressler D, Segal KR, Simpson DM, Truong D et al. Evidence-based review and assessment of botulinum neurotoxin for the treatment of movement disorders. Toxicon. 2013;67:94-114. doi:10.1016/j.toxicon.2012.12.004

99. Mundinger F. [New stereotactic treatment of spasmodic torticollis with a brain stimulation system]. Med Klin. 1977;72(46):1982-6. German.

100. Kumar R, Dagher A, Hutchison WD, Lang AE, Lozano AM. Globus pallidus deep brain stimulation for generalized dystonia: clinical and PET investigation. Neurology. 1999;53(4):871-4. doi:10.1212/WNL.53.4.871

101. Vidailhet M, Jutras MF, Grabli D, Roze E. Deep brain stimulation for dystonia. Neurol Neurosurg Psychiatry. 2013;84(9):1029-42. doi:10.1136/jnnp-2011-301714

102. Panov F, Gologorsky Y, Connors G, Tagliati M, Miravite J, Alterman RL. Deep brain stimulation in DYT1 dystonia: a 10-year experience. Neurosurgery. 2013;73(1):86-93. doi:10.1227/01.neu.0000429841.84083.c8

103. Cif L, Vasques X, Gonzalez V, Ravel P, Biolsi B, Collod-Beroud G et al. Long-term follow-up of DYT1 dystonia patients treated by deep brain stimulation: An open-label study. Mov Disord. 2010;25(3):289-99. doi:10.1002/mds.22802

104. Sokal P, Rudaś M, Harat M, Szylberg Ł, Zieliński P. Deep anterior cerebellar stimulation reduces symptoms of secondary dystonia in patients with cerebral palsy treated due to spasticity. Clin Neurol Neurosurg. 2015;135:62-8. doi:10.1016/j.clineuro.2015.05.017

105. Schjerling L, Hjermind LE, Jespersen B, Madsen FF, Brennum J, Jensen SR et al.A randomized double-blind crossover trial comparing subthalamic and pallidal deep brain stimulation for dystonia.J Neurosurg. 2013;119(6):1537-45. doi:10.3171/2013.8.JNS13844

106. Mills KA, Markun LC, San Luciano M, Rizk R, Allen IE, Racine CA et al. Effect of subthalamic nucleus deep brain stimulation on dual-task cognitive and motor performance in isolated dystonia.J Neurol Neurosurg Psychiatry. 2015;86(4):404-9. doi:10.1136/jnnp-2014-307942 